\title{
The effects of adding lucerne protein concentrate to diets on the reproductive traits and blood metabolic profiles of sows and piglets
}

\author{
E. Pietrzak and E.R. Grela ${ }^{1}$ \\ University of Life Sciences in Lublin, Institute of Animal Nutrition and Bromatology, Akademicka 13, 20-950 Lublin, Poland
}

KEY WORDS: sows, piglets, lucerne, protein concentrate, growth performance
${ }^{1}$ Corresponding author: e-mail: ergrela@interia.pl
ABSTRACT. The aim of the study was to estimate the effects of supplementing different amounts of lucerne protein concentrate (LPC) on performance, blood haematological and biochemical parameters of sows and their offspring. LPC was added in amounts of $1.5 \%$ or $3.0 \%$ to the feed mixtures for sows during gestation and lactation (Trial I, continuous use of LPC) or only during gestation or lactation (Trial II, periodic use of LPC) and for their offspring from birth to day 84. Production results were based on: number of liveborn and weaned piglets, daily gains, average feed intake, feed conversion ratio and mortality. Blood samples were collected to estimate haematological and biochemical indices. Compared with the control groups, addition of 3.0\% LPC during gestation significantly increased $(P \leq 0.05)$ average piglet birth weight, number of liveborn piglets and weaned piglets at day 28 . Diets containing $1.5 \%$ and $3.0 \%$ LPC decreased losses of piglets by day 84 ( $P \leq 0.05)$. The diet including LPC significantly $(P \leq 0.05)$ increased haematological indices: red blood cell count, haematocrit level, haemoglobin content, and biochemical parameters, especially alkaline phosphatase activity $(P \leq 0.01)$ in sow and piglet serum. The noticeable effect of LPC on haematological indices could be useful, especially in the piglet rearing period. Our results show that the best effects could be obtained by adding $3.0 \%$ LPC to the sows' diets, but $1.5 \%$ of LPC can also be recommended in pig nutrition.

\section{Introduction}

Removal of antibiotic growth promoters (AGPs) from the market and banning their use in feeds has promoted studies on alternative sources of biologically active supplements that can be effectively incorporated into pig diets (Lainea et al., 2014). Intensive research has shown that various lucernebased preparations should be considered as feed additives (Bourdon et al., 1980; Ueda and Ohshima, 1989; Grela et al., 2008; Davys et al., 2011).
Lucerne protein concentrate (LPC) contains about $55 \%$ crude protein, over $1200 \mathrm{mg}$ of xanthophylls per kilogram of preparation and a high number of active substances, including saponin glycosides ( $2 \%-3 \%)$, polyphenolic compounds with oestrogenic activity (biochanin $A$, daidzein), vitamins (A, $B_{1}$, $\left.\mathrm{B}_{6}, \mathrm{~B}_{12}, \mathrm{C}, \mathrm{E}, \mathrm{K}\right)$, provitamins ( $\beta$-carotene) and minerals (EFSA, 2009; Grela and Pietrzak, 2014). Such a potent source of biologically active substances in LPC can affect pig metabolism and thus, performance and blood metabolic profile. 
The objective of the present research was to determine the effect of supplementing lucerne protein concentrate (LPC) to sow feeds during gestation and lactation, as well as in the piglet rearing period (to 84 days of age) on performance effects and blood haematological and biochemical parameters. The studies examined two LPC levels $(1.5 \%$ and $3.0 \%)$ throughout the whole reproductive and rearing period or a $3.0 \%$ periodic level only during gestation or lactation.

\section{Material and methods}

\section{Animals, dietary treatment and management}

Two dietary treatments were performed on 60 crossbreed sows (Polish Landrace $\times$ Polish Large White) mated to Duroc boars and their offspring to the end of the piglet rearing period ( 84 days of age) during March-October 2011 (Trial I) and JanuaryAugust 2012 (Trial II). In Trial I 60 sows in the second reproductive cycle were randomly allocated to one of three feeding groups: control (without additive), 1.5\% LPC (E-15), 3.0\% LPC (E-30) for the entire experimental period. Trial II included the same 60 sows in their third reproductive cycle and three feeding groups, i.e. control, group E-30G that received a mixture with $3.0 \%$ LPC additive during gestation, and group E-30L fed the 3.0\% LPC-supplemented mixture only during lactation. From the beginning of creep feeding to day 14 post weaning, the piglets ate prestarter feeds, while from days 43 to 84 of age, the starter diet. In each dietary treatment the piglets during creep feeding and after weaning were allocated to 3 groups: control (no supplement), piglets from E-15 and E-30 were fed a mixture with $1.5 \%$ or $3.0 \%$ LPC additive, respectively, whereas the animals from E-30G and E-30L received a 3.0\% LPC-supplemented diet. The chemical composition and concentration of active ingredients of LPC are shown in Table 1, formulation and nutritive value of diets for sows are presented in Table 2 and in Table 3 for piglets. The changes in the body weight of sows were recorded by weighing animals at mating, day 110 of gestation, 2 days post partum, and after weaning the piglets, whereas feed intake was measured during gestation and lactation. The number of piglets born and reared, their weight at birth, on weaning and on day 84 of age at the end of the rearing period were recorded. In addition, feed intake was measured during creep feeding and after weaning to day 84 of life, and the causes of piglet mortality were determined.
Table 1. Chemical composition, mineral concentration and active ingredients content in lucerne protein concentrate (LPC) (Grela and Pietrzak, 2014)

\begin{tabular}{lrlr}
\hline Nutrients, $\mathrm{g} \cdot \mathrm{kg}^{-1}$ & \multicolumn{3}{l}{ Macroelements, $\mathrm{g} \cdot \mathrm{kg}^{-1}$} \\
\hline Dry matter & 910.4 & Calcium & 32.9 \\
Crude ash & 102.3 & Phosphorus & 7.9 \\
Ether extract & 103.7 & Magnesium & 1.5 \\
Crude fibre & 5.9 & Potassium & 7.4 \\
Crude protein & 533.9 & Sodium & 0.13 \\
N-free extractives & 164.6 & & \\
\hline Vitamins and saponins, $\mathrm{mg} \cdot \mathrm{kg}^{-1}$ & Microelements, $\mathrm{mg} \cdot \mathrm{kg}^{-1}$ \\
\hline a-tocopherol & 428.2 & Iron & 497.0 \\
B-carotene & 303.7 & Manganese & 81.8 \\
Vitamin K & 95.3 & Copper & 10.2 \\
L-canavanine & 3.2 & Zinc & 19.4 \\
Saponins, $\mathrm{g} \cdot \mathrm{kg}^{-1}$ & 10.39 & & \\
\hline
\end{tabular}

\section{Feed and blood analysis}

Feed samples were assayed for the contents of basic nutrients and detergent fibre fraction (AOAC, 2012). The energy value of diets was calculated using the equation proposed by Kirchgessner and Roth (1983). Blood for laboratory evaluation was collected from the external jugular vein (vena jugularis externa) from eight sows on day 84 of gestation and 21 of lactation, eight piglets ( 28 days of age) and weaner (84 days of age) from each group. The following haematological parameters were determined in whole blood using an Abacus Junior Vet analyzer: red blood cell count (RBC), haemoglobin concentration $(\mathrm{Hb})$, haematocrit $(\mathrm{Ht})$, white blood cell count (WBC) as well as their percentages: lymphocytes (LYM), middle-sized cells (MID) and granulocytes (GRA). Blood plasma was analysed for concentration of glucose (GLU), total protein (TP), blood urea nitrogen (BUN), uric acid (UA) and triacylglycerols (TG) using a colorimetric method and monotests from PZ Cormay SA (Łomianki, Poland). The urea level and activity of the following enzymes: lactate dehydrogenase (LDH), alanine aminotransferase (ALT), aspartate aminotransferase (AST) and alkaline phosphatase (ALP) were established by the kinetic method using monotests from PZ Cormay SA (Łomianki, Poland). The readings of the determined biochemical parameters in blood plasma were made using a CARY 50 Spectrophotometer (Varian, Inc., Palo Alto, CA, USA).

\section{Statistical analysis}

The hypothesis of the empirical normal distribution of recorded traits was verified using ShapiroWilk test. It was found no statistically significant deviations from the normal distribution. The data were 
evaluated statistically using a general linear model of one-way analysis of variance. Duncan's test was applied for the multiple comparisons between treatment means. These computations were performed by the use of the Statistica Software v.6.1 (2003).

\section{Results}

\section{Animal performance}

Substitution of soyabean meal by LPC in the experimental diets for sows (Table 2) and piglets (Table 3) contributed only slightly to nutrient content variation. The initial body weight $(\mathrm{BW})$ of sows in both dietary treatments averaged $170 \mathrm{~kg}$ (Table 4). In Trial I in late gestation (110 days), the body weight of animals from E-15 and E-30 differed significantly $(P \leq 0.05)$ as compared with the control sows. The sows fed the 1.5\% and 3\% LPC-supplemented diets were heavier by 4.1 and $5.9 \mathrm{~kg}$, respectively. In Trial II, on day 110 of gestation, a significantly higher weight of sows was found only in group E-30G. In both experiments, sow BW after farrow- ing did not differ significantly. The sows that after lactation received 3.0\% LPC in groups E-30 and E-30L showed a smaller weight loss compared with the control. Feed intake in both treatments during gestation and lactation did not differ significantly among the animal groups under study. The production performance of piglets is presented in Table 4 . In Trial I, the sows receiving 3.0\% LPC had a significantly higher number of liveborn piglets than in the control, and the average piglet birth weight was also significantly higher in both experimental groups: by $5.5 \%$ and $6.7 \%$ in groups E-15 and E-30, respectively. After 28 lactation days, a higher number of weanling piglets $(P \leq 0.05)$ from the sows in the experimental groups (E-15 and E-30) was recorded as compared with the control. Piglet weaning weight did not differ significantly among the groups, however. It is noteworthy that during the rearing time with sows, a lower piglet mortality rate was noted in the treatment groups in which the sows were given the lucerne protein concentrate at 15 and $30 \mathrm{~g}$ per kilogram of mixture. Piglet losses were lower by

Table 2. Chemical composition and nutritive value of mixtures for sows in gestation and lactation period

\begin{tabular}{|c|c|c|c|c|c|c|}
\hline \multirow{4}{*}{ Indices } & \multicolumn{6}{|c|}{ Reproductive period } \\
\hline & \multicolumn{3}{|c|}{ LP (gestation) } & \multicolumn{3}{|c|}{ LL (lactation) } \\
\hline & \multicolumn{6}{|c|}{ experimental groups } \\
\hline & control & $\mathrm{E}-15$ & E-30 & control & $\mathrm{E}-15$ & E-30 \\
\hline \multicolumn{7}{|l|}{ Ingredients, $\mathrm{g} \cdot \mathrm{kg}^{-1}$} \\
\hline barley & 555 & 555 & 555 & 285 & 285 & 285 \\
\hline wheat & 100 & 100 & 100 & 300 & 300 & 300 \\
\hline oat & 200 & 200 & 200 & 100 & 100 & 100 \\
\hline dried grass & 50 & 50 & 50 & 50 & 50 & 50 \\
\hline fish meal & - & - & - & 30 & 30 & 30 \\
\hline soyabean meal & 60 & 45 & 30 & 180 & 165 & 150 \\
\hline soyabean oil & - & - & - & 20 & 20 & 20 \\
\hline lucerne concentrate PX & - & 15 & 30 & - & 15 & 30 \\
\hline fodder chalk & 11 & 11 & 11 & 12 & 12 & 12 \\
\hline 2-calcium phosphate & 10 & 10 & 10 & 10 & 10 & 10 \\
\hline $\mathrm{NaCl}$ & 4 & 4 & 4 & 4.0 & 4.0 & 4.0 \\
\hline vitamin-mineral premix ${ }^{1}$ & 10 & 10 & 10 & 10 & 10 & 10 \\
\hline lysine $\mathrm{HCl}$ & - & - & - & 3 & 3 & 3 \\
\hline \multicolumn{7}{|c|}{ Nutritional value (determined), $\mathrm{g} \cdot \mathrm{kg}^{-1} \mathrm{DM}$} \\
\hline crude protein & 143.3 & 143.4 & 143.5 & 191.6 & 191.7 & 191.8 \\
\hline lysine & 5.49 & 5.53 & 5.54 & 12.48 & 12.51 & 12.55 \\
\hline crude fibre & 59.6 & 59.5 & 59.5 & 47.3 & 47.3 & 47.2 \\
\hline NDF & 273.8 & 273.5 & 273.4 & 241.6 & 241.5 & 241.3 \\
\hline ADF & 93.6 & 93.7 & 93.7 & 84.2 & 84.2 & 84.3 \\
\hline$A D L$ & 12.7 & 12.7 & 12.7 & 9.7 & 9.7 & 9.7 \\
\hline $\mathrm{Ca}$ & 7.44 & 7.46 & 7.54 & 9.24 & 9.27 & 9.28 \\
\hline total $P$ & 5.56 & 5.60 & 5.63 & 6.40 & 6.41 & 6.44 \\
\hline metabolizable energy ${ }^{2}, \mathrm{MJ} \cdot \mathrm{kg}^{-1}$ & 11.81 & 11.81 & 11.81 & 12.42 & 12.42 & 12.42 \\
\hline
\end{tabular}

E-15 - 15 g LPC per kg mixture; E-30 - 30 g LPC per kg mixture; ${ }^{1}$ vitamin-mineral premix: g: Ca $5\left(\mathrm{CaCO}_{3}\right) /\left(\mathrm{Ca}_{2}\left(\mathrm{H}_{2} \mathrm{PO}_{4}\right) /\left(\mathrm{Cal}_{2}\right), \mathrm{P} 1.3\left(\mathrm{Ca}\left(\mathrm{H}_{2} \mathrm{PO}\right)_{4}\right)\right.$; mg: Fe $100\left(\mathrm{Fe}\left(\mathrm{SO}_{4}\right) \times 7 \mathrm{H}_{2} \mathrm{O}\right)$, Zn $100(\mathrm{ZnO}), \mathrm{Cu} 23\left(\mathrm{CuSO}_{4} \times 5 \mathrm{H}_{2} \mathrm{O}\right)$, I $1.2\left(\mathrm{Cal}_{2}\right)$, Se $0.3\left(\mathrm{Na}_{2} \mathrm{SeO}_{3}\right)$; IU: vit. A 8.000; vit. $\mathrm{D}_{3} 1.000$; vit. E 60, vit. K 0.60; riboflavin 4, niacin 22, pantothenic acid 15 , vit. $B_{12} 0.02$, choline 750 ; NDF - neutral detergent fibre, ADF - acid detergent fibre, ADL - acid detergent lignin; ${ }^{2}$ metabolizable energy according to the equation of Kirchgessner and Roth (1983) 
Table 3. Chemical composition and nutritive value of mixtures for piglets

\begin{tabular}{|c|c|c|c|c|c|c|}
\hline \multirow{3}{*}{ Indices } & \multicolumn{3}{|c|}{ Prestarter } & \multicolumn{3}{|l|}{ Starter } \\
\hline & \multicolumn{6}{|c|}{ experimental groups } \\
\hline & control & $\mathrm{E}-15^{1}$ & E-301 & control & E-15 & E-30 \\
\hline \multicolumn{7}{|l|}{ Ingredients, $\mathrm{g} \cdot \mathrm{kg}^{-1}$} \\
\hline barley & - & - & - & 220.0 & 220.0 & 220.0 \\
\hline wheat & 509.0 & 509.0 & 509.0 & 412.5 & 412.5 & 412.5 \\
\hline maize & 200.0 & 200.0 & 200.0 & 200.0 & 200.0 & 200.0 \\
\hline skimmed milk powder & 80.0 & 80.0 & 80.0 & - & - & - \\
\hline fish meal & 50.0 & 50.0 & 50.0 & 30.0 & 30.0 & 30.0 \\
\hline soyabean meal & 40.0 & 25.0 & 10.0 & 100.0 & 85.0 & 70.0 \\
\hline lucerne concentrate PX & - & 15.0 & 30.0 & - & 15.0 & 30.0 \\
\hline soyabean oil & 30.0 & 30.0 & 30.0 & 10.0 & 10.0 & 10.0 \\
\hline saccharose & 50.0 & 50.0 & 50.0 & - & - & - \\
\hline fodder chalk & 5.5 & 5.5 & 5.5 & 6.0 & 6.0 & 6.0 \\
\hline 1-calcium phosphate & 4.0 & 4.0 & 4.0 & 4.0 & 4.0 & 4.0 \\
\hline $\mathrm{NaCl}$ & 2.8 & 2.8 & 2.8 & 3.0 & 3.0 & 3.0 \\
\hline vitamin-mineral premix² & 20.0 & 20.0 & 20.0 & 10.0 & 10.0 & 10.0 \\
\hline lysine $\mathrm{HCl}$ & 8.0 & 8.0 & 8.0 & 4.3 & 4.3 & 4.3 \\
\hline DL-methionine & 0.7 & 0.7 & 0.7 & 0.2 & 0.2 & 0.2 \\
\hline \multicolumn{7}{|c|}{ Nutritional value (determined), $\mathrm{g} \cdot \mathrm{kg}^{-1} \mathrm{DM}$} \\
\hline crude protein & 224.7 & 224.8 & 224.9 & 183.5 & 183.6 & 183.8 \\
\hline lysine & 15.67 & 15.72 & 15.75 & 11.26 & 11.29 & 11.31 \\
\hline crude fibre & 24.1 & 24.1 & 24.0 & 31.7 & 31.6 & 31.5 \\
\hline $\mathrm{NDF}^{3}$ & 118.4 & 118.5 & 118.5 & 176.1 & 176.3 & 176.2 \\
\hline $\mathrm{ADF}^{3}$ & 42.2 & 42.4 & 42.3 & 44.9 & 44.8 & 44.7 \\
\hline $\mathrm{ADL}^{3}$ & 5.42 & 5.41 & 5.42 & 16.7 & 16.7 & 16.7 \\
\hline $\mathrm{Ca}$ & 6.42 & 6.44 & 6.59 & 5.13 & 5.17 & 5.16 \\
\hline total $P$ & 5.65 & 5.69 & 5.73 & 5.19 & 5.21 & 5.20 \\
\hline metabolizable energy ${ }^{4}, \mathrm{MJ} \cdot \mathrm{kg}^{-1}$ & 13.12 & 13.12 & 13.12 & 12.53 & 12.53 & 12.53 \\
\hline
\end{tabular}

${ }^{1}$ see Table 2; ${ }^{2}$ vitamin-mineral premix: g: Ca $5\left(\mathrm{CaCO}_{3}\right) /\left(\mathrm{Ca}\left(\mathrm{H}_{2} \mathrm{PO}_{4}\right) /\left(\mathrm{Cal}_{2}\right), \mathrm{P} 1.3\left(\mathrm{Ca}\left(\mathrm{H}_{2} \mathrm{PO}_{4}\right), \mathrm{mg}: \mathrm{Fe} 100\left(\mathrm{Fe}\left(\mathrm{SO}_{4}\right) \times 7 \mathrm{H}_{2} \mathrm{O}\right), \mathrm{Zn} 100(\mathrm{ZnO})\right.\right.$, Cu $23\left(\mathrm{CuSO}_{4} \times 5 \mathrm{H}_{2} \mathrm{O}\right)$, I $1.2\left(\mathrm{Cal}_{2}\right)$, Se $0.3\left(\mathrm{Na}_{2} \mathrm{SeO}_{3}\right)$; IU: vit. A 8.000, vit. $\mathrm{D}_{3} 1.000, \mathrm{E} 60$, vit. K 0.60, riboflavin 4, niacin 22, pantothenic acid 15, vit. $\mathrm{B}_{12} \mathrm{0.02}$, choline $750 ;{ }^{3}$ see Table $2 ;{ }^{4}$ metabolizable energy according to the equation of Kirchgessner and Roth (1983)

Table 4. Sows body weight and feed intake during gestation and lactation

\begin{tabular}{|c|c|c|c|c|c|c|c|}
\hline \multirow{2}{*}{ Indices } & \multicolumn{3}{|l|}{ Trial I } & \multicolumn{3}{|l|}{ Trial II } & \multirow{2}{*}{ SEM } \\
\hline & control & $E-15^{1}$ & $\mathrm{E}-30^{1}$ & control & E-30G & E-30L & \\
\hline Sows, No. & 20 & 20 & 20 & 20 & 20 & 20 & - \\
\hline \multicolumn{8}{|l|}{ Body weight, kg } \\
\hline at mating & 169.4 & 170.2 & 168.9 & 172.8 & 173.4 & 172.5 & 5.63 \\
\hline at $110 \mathrm{~d}$ of gestation & $194.3^{\mathrm{a}}$ & $198.4^{b}$ & $200.2^{b}$ & $197.5^{\mathrm{a}}$ & $202.8^{b}$ & $198.4^{\mathrm{a}}$ & 5.96 \\
\hline after farrowing & 178.1 & 179.7 & 178.4 & 181.4 & 183.9 & 182.8 & 6.14 \\
\hline at weaning & $171.5^{\mathrm{a}}$ & $173.1^{\mathrm{ab}}$ & $175.4^{b}$ & $174.3^{a}$ & $177.5^{\mathrm{ab}}$ & $179.5^{b}$ & 5.72 \\
\hline \multicolumn{8}{|l|}{ Feed intake, kg per sow } \\
\hline during gestation & 2.65 & 2.67 & 2.71 & 2.66 & 2.69 & 2.65 & 0.09 \\
\hline during lactation & 5.88 & 5.91 & 5.95 & 5.84 & 5.91 & 5.83 & 0.28 \\
\hline
\end{tabular}

${ }^{1}$ see Table 2; E-30G - $30 \mathrm{~g}$ LPC per kg gestation mixture; E-30L - $30 \mathrm{~g}$ LPC per kg lactation mixture; SEM - standard error mean; ${ }^{a, b}$ values in experiment I or II in the same rows with different letters differ significantly $(P \leq 0.05)$

$1.76 \%$ and $2.19 \%$, respectively, against the control. through lactation (Trial II) were characterized by During lactation, piglet weight gains did not differ a higher number of liveborn piglets $(P \leq 0.05)$ than significantly among the groups, whereas the total sows from the control group. The birth weight of feed intake of piglets during lactation was signifi- piglets from group E-30G sows was higher comcantly lower in group E-30 than in the other groups. pared with that of piglets from the control and The sows fed the 3.0\% LPC-supplemented diet only E-30L groups. Similarly as the liveborn piglets, on 
the weaning day the E-30G sows had the largest litters. Piglet weaning weight in Trial II did not differ significantly among the groups and the same holds true for weight gain and feed intake. Piglet mortality rates during the lactation period were the lowest in the group with the LPC dietary additive supplied at lactation: $4.6 \%$. This value proved to be significantly lower compared with the control and E-30G groups (6.3\% and $6.1 \%$, respectively).

The results concerning the period after piglet weaning to day 84 of age were close in Trials I and II regarding final body weight, piglet daily weight gains, feed intake and feed conversion. Statistically significant differences were found only for piglet mortality rate. Similarly to the lactation period, lower piglet mortality in Trial I was noted in groups E-15 and E-30 as compared with the control. The same relation was observed for diarrhoea mortality when the lowest losses occurred in the experimental groups (E-15, 3.5\% and E-30, 3.4\%). In Trial II, lower piglet mortality was noted only for those from E-30L sows; it was significantly lower $(8.1 \%)$ compared with the control (10.7\%) and E-30G (11.3\%) groups.

\section{Blood indices of sows in gestation}

Table 5 summarizes the haematological and biochemical blood indices of sows during gestation. The red blood cell count (RBC) in Trial I was highest in group E-30. In Trial II, however, the E-30G sows has a higher RBC count, while in group E-30L the red blood cell concentration did not differ from that in control sows. A higher haemoglobin $(\mathrm{Hb})$ level than in the controls was found in the sows from groups E-15 and E-30 (Trial I) and E-30G (Trial II). The haematocrit (Ht) in Trial I was the highest $(\mathrm{P} \leq 0.05)$ for the sows from group E-30, whereas in Trial II, from E-30G. A significantly higher WBC count in Trial I was determined in the blood samples obtained from the sows receiving 1.5\% lucerne preparation in their diet, while in Trial II, no statistically significant differences for this index were noted. The continuous LPC supplementation contributed to a significantly elevated total protein (TP) content in blood in groups E-15 and E-30, as well as in E-30G (Trial II). No significant differences were found among the groups in glucose and triglycerides in both dietary treatments. In Trial I, the lowest uric acid content (UA) was in blood of E-15 sows, while the lowest urea level (BUN) in group E-30. In Trial II, only for uric acid, the lowest contents were recorded in group E-30G. Statistically significant differences in lactic dehydrogenase (LDH) activity, were found only in Trial I, importantly, the activity was highest in group E-15. Statistically significant differences were also found in the activity of ALP and ALT (Table 6).

Table 5. Growth performance of piglets fed a mixture with LPC addition

\begin{tabular}{|c|c|c|c|c|c|c|c|}
\hline \multirow{2}{*}{ Indices } & \multicolumn{3}{|l|}{ Trial I } & \multicolumn{3}{|l|}{ Trial II } & \multirow{2}{*}{ SEM $^{5}$} \\
\hline & control & $E-15^{1}$ & $E-30^{2}$ & control & $E-30 G^{3}$ & $E-30 L^{4}$ & \\
\hline \multicolumn{8}{|l|}{ Average No. of piglets } \\
\hline born alive & $11.87^{\mathrm{a}}$ & $12.14^{\mathrm{ab}}$ & $12.27^{b}$ & $11.75^{\mathrm{a}}$ & $12.20^{\mathrm{b}}$ & $11.90^{\mathrm{ab}}$ & 0.12 \\
\hline weaned in $28 \mathrm{~d}$ & $11.33^{a}$ & $11.78^{\mathrm{b}}$ & $11.93^{b}$ & $11.01^{a}$ & $11.45^{b}$ & $11.35^{\mathrm{ab}}$ & 0.11 \\
\hline \multicolumn{8}{|l|}{ Total number of piglets } \\
\hline born alive & 237 & 243 & 245 & 235 & 244 & 238 & 1.71 \\
\hline at $28 \mathrm{~d}$ & 226 & 236 & 239 & 220 & 229 & 227 & 2.82 \\
\hline at $84 \mathrm{~d}$ & 216 & 229 & 232 & 210 & 217 & 219 & 3.46 \\
\hline \multicolumn{8}{|l|}{ Losses of piglets, $\%$} \\
\hline to $28 \mathrm{~d}$ & $4.64^{\mathrm{b}}$ & $2.88^{\mathrm{a}}$ & $2.45^{\mathrm{a}}$ & $6.30^{\mathrm{b}}$ & $6.15^{b}$ & $4.62^{\mathrm{a}}$ & 0.42 \\
\hline to $84 \mathrm{~d}$ & $8.81^{b}$ & $5.83^{\mathrm{a}}$ & $5.26^{\mathrm{a}}$ & $10.75^{b}$ & $11.27^{b}$ & $8.08^{\mathrm{a}}$ & 0.94 \\
\hline caused by diarrhoea & $7.15^{b}$ & $3.49^{\mathrm{a}}$ & $3.43^{a}$ & $8.02^{b}$ & $7.84^{b}$ & $5.56^{\mathrm{a}}$ & 1.11 \\
\hline \multicolumn{8}{|l|}{ Body weight, kg } \\
\hline at birth & $1.64^{\mathrm{a}}$ & $1.73^{b}$ & $1.75^{b}$ & $1.62^{\mathrm{a}}$ & $1.72^{b}$ & $1.61^{\mathrm{a}}$ & 0.02 \\
\hline at $28 \mathrm{~d}$ & 7.29 & 7.43 & 7.39 & 7.18 & 7.21 & 7.39 & 0.18 \\
\hline at $84 \mathrm{~d}$ & 30.12 & 30.95 & 30.59 & 29.47 & 30.22 & 30.52 & 0.31 \\
\hline \multicolumn{8}{|c|}{ Average daily gains, $g \cdot d^{-1}$} \\
\hline $1-28 d$ & 208 & 211 & 209 & 199 & 196 & 206 & 8.2 \\
\hline 29-84 d & 408 & 420 & 414 & 398 & 411 & 413 & 20.3 \\
\hline \multicolumn{8}{|l|}{ Feed intake, $\mathrm{kg}$} \\
\hline $1-28 d$ & $5.07^{\mathrm{b}}$ & $4.92^{\mathrm{ab}}$ & $4.82^{\mathrm{a}}$ & 5.09 & 5.06 & 5.08 & 0.04 \\
\hline $29-84 d$ & 828 & 836 & 831 & 835 & 837 & 829 & 10.4 \\
\hline \multicolumn{8}{|c|}{ Feed conversion ratio, $\mathrm{kg} \cdot \mathrm{kg}^{-1}$} \\
\hline $29-84 d$ & 2.03 & 1.99 & 2.01 & 2.10 & 2.04 & 2.01 & 0.07 \\
\hline
\end{tabular}

${ }^{1-5}$ see Tables 2 and 4 ; a,b - values in experiment I or II in the same rows with different letters differ significantly $(P \leq 0.05)$ 
Table 6. Blood parameters of sows during gestation

\begin{tabular}{|c|c|c|c|c|c|c|c|}
\hline \multirow{2}{*}{ Indices } & \multicolumn{3}{|l|}{ Trial I } & \multicolumn{3}{|l|}{ Trial II } & \multirow{2}{*}{ SEM $^{5}$} \\
\hline & control & $E-15^{1}$ & $\mathrm{E}-30^{2}$ & control & $\mathrm{E}-30 \mathrm{G}^{3}$ & $E-30 L^{4}$ & \\
\hline \multicolumn{8}{|c|}{ Haematological indices } \\
\hline $\mathrm{RBC}, 10^{12} \cdot \mathrm{I}^{-1}$ & $5.92^{\mathrm{a}}$ & $6.23^{\mathrm{ab}}$ & $6.55^{\mathrm{b}}$ & $5.98^{\mathrm{a}}$ & $6.51^{\mathrm{b}}$ & $5.94^{\mathrm{a}}$ & 0.059 \\
\hline $\mathrm{Hb}, \mathrm{mmol} \cdot \mathrm{I}^{-1}$ & $6.46^{a}$ & $7.07^{\mathrm{b}}$ & $7.15^{b}$ & $6.42^{\mathrm{a}}$ & $7.19^{b}$ & $6.48^{\mathrm{a}}$ & 0.079 \\
\hline $\mathrm{Ht}, \%$ & $37.12^{\mathrm{a}}$ & $38.29^{a b}$ & $39.84^{b}$ & $36.71^{\mathrm{a}}$ & $39.18^{b}$ & $36.86^{\mathrm{a}}$ & 0.375 \\
\hline WBC, $10^{9} \cdot \mathrm{I}^{-1}$ & $15.43^{\mathrm{ab}}$ & $16.46^{b}$ & $14.36^{\mathrm{a}}$ & 15.24 & 14.11 & 15.29 & 0.338 \\
\hline GRA, $\%$ & $44.03^{\mathrm{A}}$ & $49.44^{\mathrm{AB}}$ & $54.24^{\mathrm{B}}$ & $44.58^{\mathrm{A}}$ & $53.51^{\mathrm{B}}$ & $45.46^{A}$ & 1.68 \\
\hline LYM, \% & $51.15^{\mathrm{B}}$ & $46.97^{\mathrm{B}}$ & $40.69^{A}$ & $50.64^{\mathrm{B}}$ & $42.92^{\mathrm{A}}$ & $49.87^{\mathrm{B}}$ & 1.26 \\
\hline MID, $\%$ & 4.82 & 5.08 & 3.59 & 4.78 & 3.57 & 4.67 & 0.321 \\
\hline \multicolumn{8}{|l|}{ Biochemical indices } \\
\hline $\mathrm{TP}, \mathrm{g} \cdot \mathrm{I}^{-1}$ & $89.45^{a}$ & $97.36^{b}$ & $97.00^{b}$ & $89.24^{\mathrm{a}}$ & $97.43^{b}$ & $89.78^{a}$ & 0.903 \\
\hline $\mathrm{GLU}, \mathrm{mmol} \cdot \mathrm{I}^{-1}$ & 5.54 & 5.49 & 5.57 & 5.42 & 5.53 & 5.48 & 0.046 \\
\hline $\mathrm{TG}, \mathrm{mmol} \cdot \mathrm{I}^{-1}$ & 1.10 & 1.02 & 1.04 & 1.14 & 1.17 & 1.09 & 0.010 \\
\hline $\mathrm{UA}, \mathrm{mmol} \cdot \mathrm{I}^{-1}$ & $1.43^{b}$ & $1.31^{\mathrm{ab}}$ & $1.23^{\mathrm{a}}$ & $1.48^{\mathrm{b}}$ & $1.21^{\mathrm{a}}$ & $1.45^{b}$ & 0.019 \\
\hline $\mathrm{BUN}, \mathrm{mmol} \cdot \mathrm{I}^{-1}$ & $8.68^{b}$ & $7.16^{a}$ & $7.79^{a b}$ & 8.84 & 7.95 & 8.73 & 0.211 \\
\hline $\mathrm{LDH}, \mathrm{U} \cdot \mathrm{H}^{-1}$ & $673^{a}$ & $751^{b}$ & $681^{a}$ & 687 & 698 & 676 & 5.81 \\
\hline$A L P, U \cdot I^{-1}$ & $149.2^{B}$ & $87.5^{\mathrm{A}}$ & $87.0^{\mathrm{A}}$ & $153.7^{\mathrm{B}}$ & $93.4^{\mathrm{A}}$ & $147.9^{B}$ & 6.21 \\
\hline $\mathrm{ALT}, \mathrm{U} \cdot \mathrm{I}^{-1}$ & $52.2^{b}$ & $46.1^{\mathrm{a}}$ & $50.1^{\mathrm{ab}}$ & $54.7^{b}$ & $47.4^{a}$ & $55.8^{b}$ & 0.891 \\
\hline AST, $U \cdot I^{-1}$ & 22.21 & 23.08 & 22.74 & 23.17 & 24.71 & 23.83 & 0.538 \\
\hline
\end{tabular}

${ }^{1-5}$ see Table 4; RBC - red blood cells, $\mathrm{Hb}$ - haemoglobin concentration, $\mathrm{Ht}$ - haematocrit, WBC - white cell blood cell count, LYM - lymphocytes, MID - middle-sized cells, GRA - granulocytes, TP - total protein, GLU - glucose, TG -triacylglycerols UA - uric acid, BUN - blood urea nitrogen, LDH - lactate dehydrogenase, ALP - alkaline phosphatase, ALT - alanine aminotransferase, AST - aspartate aminotransferase; ${ }^{A B, a b}$ - values in experiment I or II in the same rows with different letters differ significantly at $P \leq 0.01$ and $P \leq 0.05$, respectively

\section{Blood indices of sows in lactation}

The haematological and biochemical blood indices of lactating sows are summarized in Table 7. Significantly higher $(P \leq 0.05) \mathrm{RBC}$ counts were found in the blood of the sows from groups E-15 and E-30 in Trial I and E-30L in Trial II. Both the sows fed the dietary additive at a dose of 15 and $30 \mathrm{~g}$ LPC in Trial I and 3.0\% LPC only during lactation showed higher blood haemoglobin contents as compared with the control. The sows from group E-15 in Trial I were characterized by the highest Ht, while in Trial II, the highest value of this index was

Table 7. Blood parameters of sows during lactation

\begin{tabular}{|c|c|c|c|c|c|c|c|}
\hline \multirow{2}{*}{ Indices } & \multicolumn{3}{|l|}{ Trial I } & \multicolumn{3}{|l|}{ Trial II } & \multirow{2}{*}{ SEM $^{5}$} \\
\hline & control & $E-15^{1}$ & $E-30^{2}$ & control & $E-30 G^{3}$ & $E-30 L^{4}$ & \\
\hline \multicolumn{8}{|l|}{ Haematological indices } \\
\hline $\mathrm{RBC}, 10^{12} \cdot \mathrm{I}^{-1} 6$ & $6.28^{\mathrm{a}}$ & $7.39^{\circ}$ & $7.12^{\mathrm{b}}$ & $6.31^{a}$ & $6.38^{\mathrm{a}}$ & $7.24^{b}$ & 0.067 \\
\hline $\mathrm{Hb}, \mathrm{mmol} \cdot \mathrm{I}^{-17}$ & $5.83^{\mathrm{a}}$ & $6.70^{\mathrm{b}}$ & $6.74^{b}$ & $5.89^{a}$ & $6.03^{\mathrm{a}}$ & $6.87^{b}$ & 0.097 \\
\hline $\mathrm{Ht}, \%^{8}$ & $23.35^{\mathrm{a}}$ & $31.59^{c}$ & $28.48^{b}$ & $22.59^{a}$ & $23.86^{a}$ & $27.84^{b}$ & 0.633 \\
\hline WBC, $10^{9} \cdot \mathrm{F}^{-19}$ & $11.78^{\mathrm{B}}$ & $11.78^{\mathrm{B}}$ & $8.71^{\mathrm{A}}$ & $10.89^{B}$ & $11.84^{\mathrm{AB}}$ & $9.57^{\mathrm{A}}$ & 0.319 \\
\hline GRA, $\%{ }^{10}$ & $47.74^{a}$ & $55.03^{b}$ & $59.96^{b}$ & $48.17^{a}$ & $49.21^{\mathrm{a}}$ & $58.19^{b}$ & 1.334 \\
\hline LYM, \% ${ }^{11}$ & $48.07^{\circ}$ & $41.36^{b}$ & $35.57^{\mathrm{a}}$ & $48.54^{b}$ & $47.23^{b}$ & $38.25^{\mathrm{a}}$ & 1.329 \\
\hline MID, $\%{ }^{12}$ & 4.19 & 3.61 & 4.47 & 3.29 & 3.56 & 3.66 & 0.182 \\
\hline \multicolumn{8}{|l|}{ Biochemical indices } \\
\hline $\mathrm{TP}, \mathrm{g} \cdot \mathrm{I}^{-1} 13$ & $64.46^{\mathrm{A}}$ & $70.9^{\mathrm{B}}$ & $70.72^{\mathrm{B}}$ & $64.14^{\mathrm{a}}$ & $65.87^{a}$ & $68.53^{b}$ & 0.742 \\
\hline $\mathrm{GLU}, \mathrm{mmol} \cdot \mathrm{I}^{-1} 14$ & 4.95 & 4.98 & 4.96 & 4.89 & 4,93 & 4.95 & 0.013 \\
\hline $\mathrm{TG}, \mathrm{mmol} \cdot \mathrm{l}^{-1} 15$ & $0.65^{\mathrm{a}}$ & $0.64^{\mathrm{a}}$ & $0.72^{b}$ & 0.68 & 0.69 & 0.71 & 0.014 \\
\hline $\mathrm{UA}, \mathrm{mmol} \cdot \mathrm{I}^{-1} 16$ & 0.19 & 0.15 & 0.17 & 0.18 & 0.17 & 0.16 & 0.011 \\
\hline $\mathrm{BUN}, \mathrm{mmol} \cdot \mathrm{r}^{-1} 17$ & $10.48^{b}$ & $7.10^{\mathrm{a}}$ & $7.17^{\mathrm{a}}$ & $10.56^{b}$ & $7.69^{\mathrm{a}}$ & $7.12^{\mathrm{a}}$ & 0.412 \\
\hline $\mathrm{LDH}, \mathrm{U} \cdot \mathrm{I}^{-1} 18$ & $690.6^{\mathrm{a}}$ & $764.9^{b}$ & $717.4^{\mathrm{a}}$ & $676.3^{a}$ & $682.4^{\mathrm{ab}}$ & $725.8^{\mathrm{b}}$ & 10.85 \\
\hline ALP, $U \cdot I^{-1} 19$ & $136.57^{\mathrm{B}}$ & $89.56^{\mathrm{A}}$ & $84.13^{A}$ & $139.2^{\mathrm{c}}$ & $116.5^{\mathrm{B}}$ & $89.45^{\mathrm{A}}$ & 7.09 \\
\hline ALT, $\left.U \cdot\right|^{-1} 20$ & $53.54^{\mathrm{b}}$ & $44.20^{\mathrm{a}}$ & $47.17^{a b}$ & $51.47^{\mathrm{b}}$ & $49.56^{\mathrm{ab}}$ & $46.76^{a}$ & 4.92 \\
\hline AST, $U \cdot I^{-1} 21$ & $19.93^{a}$ & $23.32^{b}$ & $21.83^{a b}$ & $19.14^{\mathrm{a}}$ & $21.11^{\mathrm{ab}}$ & $22.83^{b}$ & 1.42 \\
\hline
\end{tabular}

${ }^{1-5}$ see Tables 2 and 4; ${ }^{6-21}$ see Table 6; ${ }^{A B C, a b}$ - values in experiment I or II in the same rows with different letters differ significantly at $P \leq 0.01$ and $P \leq 0.05$, respectively 
recorded in the E-30L group. Including lucerne in lactating sow diets significantly decreased the WBC level in sow blood. A significantly higher protein level (TP) in blood was noted in groups E-15, E-30 and E-30L as compared with the control. Only in Trial I were statistically significant differences observed in the triglyceride level among the sows from group E-30 and groups E-15 and C. The uric acid content for all the groups from both dietary treatments was similar, while the urea content varied between the groups and its highest level was detected in the blood of control sows. LDH activity in Trial I in group E-30 was significantly higher than in groups E-15 and C. In Trial II, only in group E30L was higher LDH activity noted compared with the control. Incorporating LPC into sow feed significantly $(P \leq 0.01)$ reduced ALP activity. It was found that LPC dietary supplementation weakened ALT activity as compared with the control; in Trial I this effect was confirmed in group E-15, whereas in Trial II, in E-30L.

Analysis of the blood haematological and biochemical parameters of 28-day-old piglets is presented in Table 8. Trial I revealed a stronger effect of the investigated feed additive on modification of haematological indices than Trial II. In both groups, i.e. E-15 and E-30, highly significant differences were reported in haematocrit levels against the control. Only in E-30, the supplement under study contributed to increased WBC count $(P \leq 0.05)$. In addition, some significant changes were noticed in the granulocyte and lymphocyte numbers in the groups with the LPC dietary additive. Introduction of 3.0\% LPC into the diet reduced the glucose level in piglet blood. The triglyceride level in Trial I was significantly higher in group E-15 as compared with the control and E-30. Despite the significant differences in uric acid (UA) levels among the groups in Trials I and II, the investigated preparation was not found to affect the BUN level. The diet including lucerne preparation did, however, significantly reduced the activity of the studied enzymes (ALP, ALT, AST).

\section{Blood indices of weaner piglets}

The LPC-containing diets for piglets improved the erythrocyte system, increased the RBC count, haemoglobin level and haematocrit value, especially in groups E-30 and E-30L compared with the control. The LPC feed supplement promoted a decrease in the WBC count in piglet blood. Both the $1.5 \%$ and $3.0 \%$ LPC additives to piglet diets were conducive to increasing TP, but in Trial II, only in group E-30L. The piglets from groups E-15 and E-30L had the lowest blood triglyceride levels. The urea content in piglet blood throughout Trial I was highest in group E-30L and exceeded that in the control group by $0.84 \mathrm{mmol} \cdot 1^{-1}$. The activity of each enzyme in the experimental groups differed significantly as compared with the control group. Lactic dehydrogenase (LDH) activity was lower in response to feeding the experimental factor by $43 \%$ and $34 \%$, respectively, in groups E-15 and E-30, whereas in

Table 8. Blood parameters of weaned piglets at 28 days of life

\begin{tabular}{|c|c|c|c|c|c|c|c|}
\hline \multirow{2}{*}{ Indices } & \multicolumn{3}{|l|}{ Trial I } & \multicolumn{3}{|l|}{ Trial II } & \multirow{2}{*}{ SEM $^{5}$} \\
\hline & control & $E-15^{1}$ & $\mathrm{E}-30^{2}$ & control & $\mathrm{E}-30 \mathrm{G}^{3}$ & $E-30 L^{4}$ & \\
\hline \multicolumn{8}{|l|}{ Haematological indices } \\
\hline $\mathrm{RBC}, 10^{12} \cdot \mathrm{I}^{-1} 6$ & 7.41 & 7.52 & 7.57 & 7.46 & 7.53 & 7.55 & 0.07 \\
\hline $\mathrm{Hb}, \mathrm{mmol} \cdot \mathrm{l}^{-17}$ & 7.65 & 7.58 & 7.67 & 7.61 & 7.57 & 7.62 & 0.08 \\
\hline $\mathrm{Ht}, \%^{8}$ & $41.32^{B}$ & $37.61^{\mathrm{A}}$ & $38.12^{A}$ & 39.83 & 37.65 & 38.02 & 0.48 \\
\hline WBC, $10^{9} \cdot 1^{-19}$ & $11.85^{\mathrm{a}}$ & $12.27^{\mathrm{ab}}$ & $13.23^{b}$ & 11.89 & 12.04 & 12.62 & 0.25 \\
\hline GRA, $\%{ }^{10}$ & $34.63^{a}$ & $40.85^{b}$ & $38.76^{b}$ & $36.62^{a}$ & $36.98^{a}$ & $38.73^{b}$ & 1.21 \\
\hline LYM, \% ${ }^{11}$ & $63.99^{b}$ & $57.53^{\mathrm{a}}$ & $59.66^{a}$ & $61.94^{b}$ & $61.41^{\mathrm{b}}$ & $59.69^{a}$ & 1.12 \\
\hline MID, $\%{ }^{12}$ & 1.38 & 1.62 & 1.58 & 1.44 & 1.61 & 1.58 & 0.42 \\
\hline \multicolumn{8}{|l|}{ Biochemical indices } \\
\hline $\mathrm{TP}, \mathrm{g} \cdot \mathrm{1}^{-1} 13$ & 54.01 & 55.97 & 55.97 & 54.23 & 55.02 & 55.93 & 0.74 \\
\hline $\mathrm{GLU}, \mathrm{mmol} \cdot \mathrm{1}^{-1} 14$ & $6.74^{b}$ & $6.23^{a b}$ & $5.77^{a}$ & $6.53^{b}$ & $6.38^{b}$ & $5.79^{a}$ & 0.12 \\
\hline $\mathrm{TG}, \mathrm{mmol} \cdot \mathrm{1}^{-1} 15$ & $0.32^{\mathrm{a}}$ & $0.45^{b}$ & $0.28^{\mathrm{a}}$ & $0.37^{\mathrm{ab}}$ & $0.42^{b}$ & $0.32^{\mathrm{a}}$ & 0.02 \\
\hline $\mathrm{UA}, \mathrm{mmol} \cdot \mathrm{1}^{-1} 16$ & $0.15^{\mathrm{a}}$ & $0.29^{b}$ & $0.12^{\mathrm{a}}$ & $0.17^{\mathrm{ab}}$ & $0.21^{b}$ & $0.12^{\mathrm{a}}$ & 0.021 \\
\hline $\mathrm{BUN}, \mathrm{mmol} \cdot \mathrm{l}^{-1} 17$ & 6.51 & 7.18 & 7.24 & 6.85 & 6.52 & 6.34 & 0.99 \\
\hline $\mathrm{LDH}, \mathrm{U} \cdot \mathrm{I}^{-1} 18$ & 712.9 & 681.9 & 781.7 & 723.4 & 708.9 & 742.3 & 32.36 \\
\hline ALP, $U \cdot 1^{-119}$ & $227.2^{\mathrm{A}}$ & $258.9^{B}$ & $261.2^{B}$ & $223.4^{\mathrm{A}}$ & $253.5^{\mathrm{B}}$ & $264.1^{\mathrm{B}}$ & 8.13 \\
\hline$A L T, U \cdot 1^{-1} 20$ & $23.71^{\mathrm{A}}$ & $30.72^{\mathrm{B}}$ & $32.40^{\mathrm{B}}$ & $23.42^{\mathrm{A}}$ & $26.25^{\mathrm{AB}}$ & $31.35^{\mathrm{B}}$ & 0.91 \\
\hline AST, $U \cdot 1^{-121}$ & $50.21^{\mathrm{a}}$ & $57.03^{b}$ & $58.45^{b}$ & $50.2^{\mathrm{a}}$ & $56.39^{\mathrm{b}}$ & $58.07^{b}$ & 1.69 \\
\hline
\end{tabular}

${ }^{1-5}$ see Table 4; ; $6-21$ see Table 6; ${ }^{A B C, a b}$ - values in experiment I or II in the same rows with different letters differ significantly at $P \leq 0.01$ and $P \leq 0.05$, respectively 
Table 9. Blood parameters of piglets at 80 days of life

\begin{tabular}{|c|c|c|c|c|c|c|c|}
\hline \multirow{2}{*}{ Indices } & \multicolumn{3}{|l|}{ Trial I } & \multicolumn{3}{|l|}{ Trial II } & \multirow{2}{*}{ SEM $^{5}$} \\
\hline & control & $\mathrm{E}-15^{1}$ & $E-30^{2}$ & control & $E-30 G^{3}$ & E-30L ${ }^{4}$ & \\
\hline \multicolumn{8}{|l|}{ Haematological indices } \\
\hline $\mathrm{RBC}, 10^{12} \cdot \mathrm{l}^{-1} 6$ & $6.56^{\mathrm{a}}$ & $7.41^{\mathrm{b}}$ & $7.97^{b}$ & $6.39^{a}$ & $6.88^{\mathrm{ab}}$ & $7.72^{\mathrm{b}}$ & 0.167 \\
\hline $\mathrm{Hb}, \mathrm{mmol} \cdot \mathrm{I}^{-17}$ & $6.31^{a}$ & $6.47^{a b}$ & $6.77^{b}$ & $6.28^{a}$ & $6.53^{\mathrm{ab}}$ & $6.71^{\mathrm{b}}$ & 0.097 \\
\hline $\mathrm{Ht}, \%^{8}$ & $34.33^{a}$ & $37.82^{b}$ & $38.12^{b}$ & $32.94^{a}$ & $33.86^{b}$ & $34.85^{b}$ & 0.633 \\
\hline WBC, $10^{9} \cdot \mathrm{I}^{-19}$ & $16.13^{b}$ & $15.35^{\mathrm{ab}}$ & $14.23^{\mathrm{a}}$ & $15.94^{c}$ & $14.64^{b}$ & $13.57^{\mathrm{a}}$ & 0.319 \\
\hline GRA, $\%{ }^{10}$ & $55.64^{b}$ & $57.66^{b}$ & $48.76^{a}$ & $56.13^{b}$ & $55.22^{b}$ & $50.19^{a}$ & 1.334 \\
\hline LYM, \% ${ }^{11}$ & $43.03^{b}$ & $40.23^{a}$ & $49.36^{c}$ & $42.55^{\mathrm{a}}$ & $43.23^{a}$ & $48.25^{b}$ & 1.329 \\
\hline MID, $\%{ }^{12}$ & 1.33 & 2.11 & 1.88 & 1.32 & 1.55 & 1.56 & 0.182 \\
\hline \multicolumn{8}{|l|}{ Biochemical indices } \\
\hline $\mathrm{TP}, \mathrm{g} \cdot \mathrm{I}^{-113}$ & $53.71^{\mathrm{A}}$ & $57.89^{B}$ & $63.17^{\mathrm{C}}$ & $54.17^{a}$ & $55.83^{a}$ & $62.54^{\mathrm{b}}$ & 0.742 \\
\hline $\mathrm{GLU}, \mathrm{mmol} \cdot \mathrm{I}^{-1} 14$ & 6.26 & 6.03 & 6.28 & 6.07 & 5.93 & 6.15 & 0.013 \\
\hline $\mathrm{TG}, \mathrm{mmol} \cdot \mathrm{l}^{-1} 15$ & $0.77^{\mathrm{b}}$ & $0.55^{\mathrm{a}}$ & $0.61^{\mathrm{ab}}$ & $0.78^{b}$ & $0.69^{a b}$ & $0.62^{\mathrm{a}}$ & 0.014 \\
\hline $\mathrm{UA}, \mathrm{mmol} \cdot \mathrm{l}^{-1} 16$ & 0.33 & 0.34 & 0.33 & 0.38 & 0.37 & 0.34 & 0.011 \\
\hline $\mathrm{BUN}, \mathrm{mmol} \cdot \mathrm{I}^{-1} 17$ & $6.45^{\mathrm{a}}$ & $6.66^{\mathrm{a}}$ & $7.29^{b}$ & $6.54^{a}$ & $6.76^{\mathrm{ab}}$ & $7.12^{b}$ & 0.123 \\
\hline $\mathrm{LDH}, \mathrm{U} \cdot \mathrm{I}^{-1} 18$ & $987.6^{b}$ & $689.7^{\mathrm{a}}$ & $737.6^{\mathrm{a}}$ & $897.5^{\mathrm{b}}$ & $681.3^{\mathrm{a}}$ & $765.8^{\mathrm{ab}}$ & 21.85 \\
\hline$A L P, U \cdot I^{-1} 19$ & $225.6^{B}$ & $278.7^{\mathrm{A}}$ & $298.8^{A}$ & $239.2^{\mathrm{a}}$ & $246.5^{\mathrm{ab}}$ & $279.4^{b}$ & 7.09 \\
\hline$A L T, U \cdot I^{-1} 20$ & $21.05^{\mathrm{a}}$ & $21.82^{\mathrm{a}}$ & $30.01^{\mathrm{b}}$ & $21.44^{\mathrm{a}}$ & $24.53^{\mathrm{ab}}$ & $28.76^{b}$ & 0.92 \\
\hline AST, U $\cdot I^{-1} 21$ & $53.56^{a}$ & $54.13^{\mathrm{a}}$ & $60.95^{\mathrm{b}}$ & $49.17^{a}$ & $51.11^{\mathrm{a}}$ & $62.83^{b}$ & 1.42 \\
\hline
\end{tabular}

${ }^{1-5}$ see Table 4; ${ }^{6-21}$ see Table 6; ${ }^{A B C, a b}$ - values in experiment I or II in the same rows with different letters differ significantly at $P \leq 0.01$ and $P \leq 0.05$, respectively

Trial II, a statistically significant difference was reported only in group E-30G. Regarding ALP, highly significant elevation of activity was observed in Trial I, i.e. by $23 \%$ and $32 \%$, respectively, in groups E-15 and E-30, while in Trial II, only in group E-30L. In Trial I, the ALT activity increased by $42 \%$ as a result of including $3.0 \%$ LPC in sow diets. In Trial II, a significant rise of ALT activity (by $34 \%$ ) was found in group E-30L. AST activity also depended on the studied feed additive. It was found that in group E-30 the activity of ALP increased by $14 \%$, whereas in E-30L, by as much as $28 \%$ compared with the control.

\section{Discussion}

Application of plant-derived feed additives positively affects daily weight gains, feed intake and feed conversion ratio (Wang et al., 2008). This correlation was observed in the present studies, 15 and $30 \mathrm{~g}$ of LPC preparation per kilogram of feed promoted the growth of sow body weight in late gestation (Trial I), whereas in the groups fed LPC periodically, only the sows with the lucerne preparation supplied during gestation had a higher prepartum body weight. Both periodic use of the LPC preparation (during lactation) and continuous use (through the whole reproductive period) at the $3.0 \%$ level allowed for higher energy reserves in the body, which ensured better body condition of sows after lactation. Dietary incorporation of LPC increased piglet birth weight and the number of liveborn ones, especially at $3.0 \%$ during gestation $(P \leq 0.05)$. Opposing relationships were shown by Lian et al. (2004) in a study in which lucerne meal added in an amount of $20 \%$ to diets for sows in gestation had no significant effect on born litter weight or piglet weight gain, but significantly increased litter weight and piglet weight gain of weaned piglets. Phytoestrogens (coumestrol, genistein, daidzein) found in lucerne were likely to elevate piglet birth weight. The finding was confirmed by studies on sows that received a dietary supplement of daidzein in late gestation (Li et al., 1999; Ren et al., 2001). Ren et al. (2001) hypothesized that the foetal growth-promoting effect of daidzein is via activation of insulinlike growth factor (IGF-1). The preweaning piglet mortality rate depends on several factors, among others, birth weight, litter size, length of farrowing, sow milk production, structure of pens, ambient temperature and behaviour patterns of sows and piglets (Panzardi et al., 2013). In the groups fed the LPC-supplemented diet, the mortality rates of piglets up to 28 days of life were lower compared with the control. A similar relationship was highlighted in other works studying the effect of various phytobiotics on piglet rearing performance (Walter and Bilkei, 2004; Matysiak et al., 2012). Matysiak et al. (2012) reported that dietary inclusion of a phytobiotic reduced piglet mortality during lactation from $8.6 \%$ in the control to $4.5 \%$ in the experimental group. Importantly, in Trial I the mortality 
rate caused by diarrhoea was two-fold lower in the experimental groups than in the control. The active substances of herbs and some plants enhance enzyme secretion, boost the immune system and prevent diarrhoea (Matysiak et al., 2012). Lucerne saponins possess potent antibacterial properties (Avato et al., 2006; Joy and George, 2014) that contribute to the declining incidence of diarrhoea induced by E. coli in the postweaning period.

The red and white blood cell counts, haemoglobin concentration, and haematocrit value in blood of piglets and control sows indicated proper erythropoiesis and the obtained values were within the reference ranges (Friendship and Henry, 1996; Winnicka, 2004). The present study shows a significant impact of LPC on the haematological parameters of sow and piglet blood, especially the red blood cell count (RBC) and haemoglobin level (Hb). Some authors (Vyas et al., 2010; Davys et al., 2011) attribute that to the high level of iron in LPC and to this iron being readily absorbed and incorporated into human and animal red blood cells. In a study by Criste et al. (2008), 5.0\% dietary lucerne given to weaned piglets significantly influenced iron balance, however, studies on turkeys (Krauze and Grela, 2010) did not confirm the effectiveness of LPC in changing RBC indices. Vyas et al. (2010) in studies on humans associated the increased level of haemoglobin and iron in the blood collected from the experimental group with the rich mineral composition of the lucerne preparation. This pertains predominantly to Fe and $\mathrm{Cu}$, which are directly involved in haematopoiesis, but the presence of vitamin $A$ and $\beta$-carotene enhances the absorption of these elements. However, no significant influence of LPC on the level of RBC and $\mathrm{Hb}$ was noted in the case of 28-day-old pigs, as unweaned piglets exhibit low intake of solid feed and colostrum and sow's milk are a rather poor source of Fe (Hanušovský et al., 2014). A high content of biologically active compounds in LPC, e.g., saponins and daidzein (EFSA, 2009; Grela and Pietrzak, 2014), was likely to cause statistically significant differences in the WBC and LEU counts, notably as a result of the immunomodulatory effects of saponins, among others, via antibody and cytokinin production (Francis et al., 2002; Das et al., 2012). Our study found a decline in white blood cell and leucocyte counts in the experimental groups of both sows and piglets. Wang et al. (2002) found that multiple injections of $0.5 \mathrm{mg}$ daidzein per kilogram $\mathrm{BW}$ for 24 days into piglets increased WBC and LEU counts; also in other studies Wang (2007) shows the same immunostimulatory, in particular, effect of lucerne saponins on pigs and improvement in the WBC count when lucerne saponins were added at a dose of $0.5 \%$ to the pig diets. A difference between the results of the present studies may arise from the synergistic activity of a number of other biologically active substances that LPC contains. Moreover, the route of administration of an experimental factor (injection or feeding) also influences the obtained results. The activity of enzymes from the aminotransferase group and alkaline phosphatase points to the effect of the biologically active ingredients of LPC on the metabolism of some tissues and organs (e.g., the liver) of sows and piglets. The finding is consistent with the studies on fatteners conducted by Grela et al. (2008) and Pietrzak and Grela (2013), which demonstrated a significantly higher liver weight of fatteners fed $1.5 \%$ and $3.0 \%$ LPC. These authors associate the increased liver weight with the influence of bioactive compounds in the lucerne preparation. AST and ALT are enzymes recognized as indices of protein reserve mobilization in an organism in the case of a negative energy balance, while limited activity of these enzymes in the sows fed LPCsupplemented feed indicates better utilization of the protein and energy in the feed. The studies of Yang et al. (2002) also showed a significant influence of lucerne on AST activity. A different relationship was noted for alkaline phosphatase activity in piglets. ALP is involved in phosphate metabolism and the enhanced activity of this enzyme occurs mainly during growth of the skeletal system growth and during development. The LPC preparation is high in $\mathrm{Ca}$ and $\mathrm{P}$, which could favour a rise in ALP activity.

\section{Conclusions}

The results of the present study indicate that the addition of $1.5 \%$ or $3.0 \%$ of lucerne protein concentrate (LPC) to sow and piglet diets improves erythropoiesis, as manifested by the elevated red blood cell indices. The biologically active compounds contained in LPC contributed to the better performance results of sows and their piglets. Further investigations are necessary to better clarify the mechanisms involved in the effects of LPC on animal organisms. It seems that the continuous inclusion of 3.0\% LPC in sow diets can be recommended and that for piglets, LPC in amount of $1.5 \%$ can be added to starter diets in the postweaning period.

\section{Acknowledgements}

This study was supported by Project No. 12000506 from the National Center for Research and Development, Poland. 


\section{References}

AOAC, 2012. Association of Official Analytical Chemists, Official Methods of Analysis. 19th Edition. Gaithersburg, MA

Avato P., Bucci R., Tava A., Vitali C., Rosato A., Bialy Z., Jurzysta M., 2006. Antimicrobial activity of saponins from Medicago sp.: structure-activity relationship. Phytother. Res. 20, 454-457

Bourdon D., Perez J.M., Henry Y., Calmes R., 1980. Valeur énergétique et azotée d'un concentré de protéines de luzerne, le "PX1", et utilisation par le porc en croissance-finition. Journées Rech. Porcine 12, 227-244

Criste R.D., Uneta A., Panaite T., Tăranu I., 2008. Effect of the dietary alfalfa on iron balance in weaned piglets. Arch. Zootech. 11, 49-56

Das T.K., Banerjee D., Chakraborty D., Pakhira M.C., Shrivastava B., Kuhad R.C., 2012. Saponin: Role in animal system. Vet. World. 5, 248-254

Davys M.N.G., Richardier F.-C., Kennedy D., de Mathan O., Collin S.M., Subtil J., Bertin E., Davys M.J., 2011. Leaf concentrate and other benefits of leaf fractionation. In: B. Thompson, L. Amoroso (Editors). Combating Micronutrients Deficiencies: Food-based Approaches. FAO (Roma), pp. 338-365

EFSA, 2009. Opinion on the safety of "Alfalfa protein concentrate" as food. EFSA J. 997, 1-19

Francis G., Kerem Z., Makkar H.P.S., Becker K., 2002. The biological action of saponins in animal systems: a review. Brit. J. Nutr. $88,587-605$

Friendship R.M., Henry S.C., 1996. Cardiovascular system, haematology and clinical chemistry. In: A.D. Leman, B.E. Straw, W.L. Mengeling, S. D'Allaire, D.J. Taylor (Editors). Diseases of Swine. lowa State University Press (USA), pp. 3-11

Grela E.R., Pietrzak K., 2014. Production technology, chemical composition and use of alfalfa protein-xanthophyll concentrate as dietary supplement. J. Food Process. Technol. 5, 373-377

Grela E.R., Semeniuk W., Florek M., 2008. Effects of protein-xanthophyll $(P X)$ concentrate of alfalfa additive to crude proteinreduced diets on nitrogen excretion, growth performance and meat quality of pigs. J. Cent. Eur. Agr. 8, 669-676

Hanušovský O., Bíro D., Gálik B., Rolinec M., Šimko M., Juráček M., Rušinová M., 2014. Changes in the average concentration of minerals in the colostrums of sows during the first 48 hours after parturition. Res. Pig Breed. 8, 32-35

Joy G.S., George P., 2014. Antimicrobial screening of alfalfa (Medicago sativa) in various bacterial strains. Int. J. Pharm. Drug. Anal. 2, 65-69

Kirchgessner M., Roth F.X., 1983. Schätzgleichungen zur Ermittlung des energetischen Futterwertes von Mischfuttermitteln für Schweine. J. Anim. Physiol. Anim. Nutr. 50, 270-275

Krauze M., Grela E.R., 2010. The influence of the protein-xanthophyll (PX) alfalfa concentrate used as an additive in turkey diet on performance and some blood indices. Arch. Geflügelk. 74, 226-232

Lainea T., Yliahof M., Myllysa V., Pohjanvirtaa T., Fossia M., Anttila M. 2014. The effect of antimicrobial growth promoter withdrawal on the health of weaned pigs in Finland. Prev. Vet. Med. 66, 163-174
Li G., Zheng Y., Chen W., Chen J., Han Z., 1999. Effect of daidzein fed to pregnant sows on milk production and the levels of hormones in colostrum. J. Nanjing Agric. Univ. 22, 69-72

Lian H., Wang C., Yang Y., Hu X., Zhang C., 2004. Effect of adding different of alfalfa meal to gestational diet on the performance in sows and their piglets. J. Northwest Sci. Tech. Univ. Agric. Forest. 32, 35--40

Matysiak B., Jacyno E., Kawęcka M., Kołodziej-Skalska A., Pietruszka A., 2012. The effect of plant extracts fed before farrowing and during lactation on sow and piglet performance. S. Afr. J. Anim. Sci. 42, 15-21

Panzardi A., Bernardi M.L., Mellagi A.P., Bierhals T., Bortolozzo F.P., Wentz I., 2013. Newborn piglet traits associated with survival and growth performance until weaning. Prev. Vet. Med. 110, 206-213

Pietrzak K., Grela E.R., 2013. The influence of protein-xanthophyll concentrate of alfalfa on growth performance and carcass value of growing-finishing pig. Ann. UMCS, Sect. EE 31, 10-17

Ren M.Q., Kuhn G., Wegner J., Nurnberg G., Chen J., Ender K., 2001. Feeding daidzein to late pregnant sows influences the oestrogen receptor beta and type 1 insulin-like growth factor receptor mRNA expression in newborn piglets. J. Endocrinol. 170, $129-135$

StatSoft., 2003. Statistica Electronic Manual. Version 6. StatSoft Inc. Tulsa, OK (USA)

Ueda H., Ohshima M., 1989. Nutritive value of alfalfa leaf protein concentrate prepared from low saponin variety in chicks and pigs. Jpn. J. Zoot. Sci. 60, 561-566

Vyas S., Collin S.M., Bertin E., Davys G.J., Mathur B., 2010. Leaf concentrate as an alternative to iron and folic acid supplements for anaemic adolescent girls: a randomised controlled trial in India. Public. Health Nutr. 13, 418-423

Walter B.M., Bilkei G., 2004. Immunostimulatory effect of dietary oregano etheric oils on lymphocytes from growth-retarded, low-weight growing-finishing pigs and productivity. Tijdschr. Diergeneesk. 129, 178-181

Wang G., Zhang X., Han., Liu Z., Liu W., 2002. Effects of daidzein on body weight gain, serum IGF-I level and cellular immune function in intact male piglets. Asian-Austr. J. Anim. Sci. 15, 1066-1070

Wang Q., Kim H.J., Cho J.H., Chen Y.J., Yoo J.S., Min B.J., Wang Y., Kim I.H., 2008. Effects of phytogenic substances on growth performance, digestibility of nutrients, faecal noxious gas content, blood and milk characteristics and reproduction in sows and litter performance. J. Anim. Feed Sci. 17, 50-60

Wang Y.H., 2007. Effects of alfalfa saponins and alfalfa meal on the production performance and regulation mechanism of weaned piglets and finishing pigs. MS Thesis, College of Animal Science and Veterinary Medicine, Henan Agricultural University, Zhengzhou (China)

Winnicka A., 2004. The Reference Values in Veterinary Laboratory Analysis (in Polish). SGGW, Warsaw (Poland)

Yang Y., Lu D., Xu Z., Wang Y., Liu J., 2002. A study on the effects of dietary fibre on performance and serum parameters in finishing pigs. Acta Agric. Univ. Jiangxiensis. 24, 578-582 